\title{
CALLUS INDUCTION, PHYTOCHEMICAL STUDIES AND ANTIBACTERIAL ACTIVITY OF DECALEPIS ARAYALPATHRA (JOSEPH AND CHANDRAS) VENTER
}

\author{
H. R. RAVEESHA, K. S. ASHALATHA
}

Department of Botany, Bangalore University, Jnanabharathi Campus, Bengaluru 560056 Karnataka

Email: hrraveesh74@gmail.com

Received: 16 Jun 2017 Revised and Accepted: 02 Nov 2017

\section{ABSTRACT}

Objective: The aim of the present study was designed for the induction of callus from leaf explants of Decalepis arayalpathra (D. arayalpathra) and to analyse their phytochemical constituents and antibacterial activity.

Methods: The explants were cultured on Murashige and Skoog (MS) medium supplemented with different concentration of 2, 4dichlorophenoxyacetic acid (2, 4-D) and later subcultured to the combination of 6-benzylaminopurine (BAP) and 1-naphthaleneacetic acid (NAA). The phytochemical constituents were analysed in the different solvent extracts using standard methods. Antibacterial activity of the different solvent extracts was carried out using agar well diffusion method against reference standards.

Results: Callus induction was observed on MS medium supplemented with different concentration and combination of auxins and cytokinins. Maximum callus induction was noticed on media supplemented with 2, 4-D (2 mg/l) and BAP (1 mg/l)+NAA (0.5 mg/l) respectively. The phytochemical screening revealed the presence of alkaloids, flavonoids, phenols, tannins, steroids and terpenoids, glycosides, coumarins and quinone etc. All the solvent extracts showed varying degree of antibacterial activities against the bacterial strains (Bacillus subtilis, Escherichia coli, Klebsiella pneumoniae, Pseudomonas fluorescence and Staphylococcus aureus). The maximum antibacterial activity of leaf was observed in aqueous (Klebsiella pneumoniae, 19.00 \pm 1.00 ) and methanolic extract (Klebsiella pneumoniae, 18.33 \pm 1.15 ). Whereas petroleum ether extract of the callus

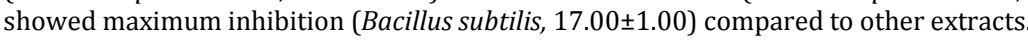

Conclusion: The study revealed the presence of secondary metabolites in the leaf and callus extracts of $D$. arayalpathra. The methanolic extracts possess higher antibacterial activity compared to other solvent extracts. However, further studies have to be carried out for the isolation and identification of antimicrobial compounds against pathogens.

Keywords: Antibacterial, Auxins, Callus, Decalepis arayalpathra, Phytochemicals

(C) 2017 The Authors. Published by Innovare Academic Sciences Pvt Ltd. This is an open access article under the CC BY license (http://creativecommons.org/licenses/by/4.0/) DOI: http://dx.doi.org/10.22159/ijpps.2017v9i12.20743

\section{INTRODUCTION}

Plants are an exemplary source of traditional medicine and pharmaceutical drugs for humankind since time immemorial. In the worldwide, it has been estimated that about 20,000 plants species are used as drugs. In India, herbal medicines have been used in the Indian traditional system of medicine (Ayurveda, Unani and Siddha) for the treatment of various diseases SD arayalpathra is one of the important medicinal plants, belonging to the family Periplocaceae, found in the southern region of the Western Ghats of India [1]. Tuberous roots of $D$. arayalpathra are consumed as pickles and as a popular cool drink known as Nannari [2-4]. The root extract was used by the kani tribes for the treatment of peptic ulcer and has a rejuvenating tonic [5]. Recent pharmacological studies have also revealed that root extract of the plant had immune-modulatory and antitumor activity [6] and as well as blood purifier [7-8]. Conventional propagation of $D$. arayalpathra is at stake with several factors like poor fruit set, seed germination and rooting on stem cutting [9-10]. Due to its high demand, the destructive harvesting of the roots leads to extinction of the species which necessitates another alternative method for propagation and conservation. Therefore, plant tissue culture techniques offer a powerful tool for mass multiplication of many plant species.

The development of drug resistance in human pathogen against commonly used antibiotics has opened a new avenue for the search of new antibacterial compounds from natural sources. Many of the plant species have been evaluated for antimicrobial properties, but the majority of them have not been systematically evaluated and a lot of attention is being derived to evaluate the plant extracts as an antibacterial agent against resistant plant pathogens. Recently, plant tissue culture techniques are used to enhance the secondary metabolite production in plants [11]. Studies on phytochemical and antibacterial activities of the in vitro regenerated callus are limited. Therefore the present study was investigated to develop an effective protocol for callus induction and to analyse their phytochemical and antibacterial activities.

\section{MATERIALS AND METHODS}

\section{Plant material}

The plants were collected from the Western Ghats, Njaraneeli, Kerala and authenticated in the Department of Botany, Bangalore University. A voucher specimen is deposited in the herbarium (BUB, No. 2268). The plants were maintained in greenhouse at Department of Botany, Bangalore University, Bengaluru.

\section{Callus induction}

Leaf explants of $D$. arayalpathra were washed under running tap water (30 $\mathrm{min})$ to remove soil particles then followed by different sterilants (bavastin and teepol). Explants were rinsed with distilled water for 2-3 times after each treatment. Finally, the explants were sterilized with $0.1 \%$ mercuric chloride for $2 \mathrm{~min}$ followed by washing with double distilled water for four times. Explants were then inoculated on MS media supplemented with different concentration of auxins $(0.5,1,2,3$ and $4 \mathrm{mg} / \mathrm{l}$ of 2, 4-D), combination of auxins $(0.5 \mathrm{mg} / \mathrm{l}$ of NAA) and cytokinins $(0.5,1,2,3$ and $4 \mathrm{mg} / \mathrm{l}$ of BAP). Cultures were maintained at $25 \pm 2{ }^{\circ} \mathrm{C}$ under white fluorescent light for $16 \mathrm{hr}$ photoperiod.

\section{Preparation for plant extracts}

10 gms of leaf and callus were grinded using mortar and pestle in different solvents (ethanol, methanol, petroleum ether, chloroform, hexane, acetone, butanol and distilled water). The extracts were filtered through Whatman No. 1 filter paper. The procedure was 
repeated for another two cycles to ensure complete extraction of phytochemical compounds [12]. The filtrates were lyophilized and stored at $4{ }^{\circ} \mathrm{C}$ until further analysis.

\section{Preliminary phytochemical analysis}

The preliminary phytochemical analysis was carried out by standard methods [13-14]. Briefly, the lyophilized extracts were dissolved in respective solvents and screened for the qualitative analysis for the presence of alkaloids, flavonoids, proteins, phenols, tannins, steroids and terpenoids, phytosterols, glycosides, coumarins, carbohydrates, betacyanin, resins, phlobatannins, starch, volatile oils, emodols [15-16].

\section{Antibacterial assay}

The solvent extracts were assayed against the following organisms Bacillus subtilis, Escherichia coli, Klebsiella pneumoniae, Pseudomonas fluorescence and Staphylococcus aureus. Bacterial strains were obtained from Department of Microbiology, Bangalore University, Bengaluru. In vitro antibacterial activity was performed by agar well diffusion method according to the protocol of Johnson et al. [17]. Wells were bored into nutrient agar using a sterile $8 \mathrm{~mm}$ diameter cork borer. Different solvent extracts $(150 \mu \mathrm{l})$ were added into the wells using sterilized pipettes and allowed to diffuse at room temperature for $2 \mathrm{~h}$. The plates were incubated at $37^{\circ} \mathrm{C}$ for $24 \mathrm{~h}$.
After the incubation, the diameter of the zone of inhibition was recorded in millimetre and compare with standard antibiotics (tetracycline and streptomycin). The experiments were repeated thrice in triplicates.

\section{Statistical analysis}

The results were expressed as mean \pm standard deviation (SD). Data were analyzed statistically by one-way analysis of variance followed by Duncan's multiple range tests using SPSS software. Probability values $p<0.05$ were considered significant.

\section{RESULTS}

\section{In vitro callus induction for leaf explants}

The induction of callus was observed from leaf explants within two weeks of inoculation on MS media supplemented with various plant growth regulators. Maximum callus induction was observed after eight weeks of cultures on MS media supplemented with $2 \mathrm{mg} / \mathrm{l}$ of 2 , 4-D and combinations of BAP ( 1 and $2 \mathrm{mg} / \mathrm{l})+\mathrm{NAA}(0.5 \mathrm{mg} / \mathrm{l}$ ) (table. 1, fig. $1 \mathrm{~A}-\mathrm{F})$. Further increase in growth hormone concentration, decrease in the percent of callus induction. The morphology and growth of the callus were affected by varying concentration of 2, 4-D (creamish callus) and the combination of BAP+NAA (green friable callus). There was no callus induction on basal medium.

Table 1: Effect of plant growth hormones on callus induction from leaf explants of $D$. arayalpathra

\begin{tabular}{llll}
\hline Growth regulators & Concentration & \% response \pm SD & Nature of callus \\
\hline $2,4-\mathrm{D}$ & $0.5 \mathrm{mg} / \mathrm{l}$ & $80.00 \pm 5.00^{\text {cd }}$ & Creamish callus \\
& $1.0 \mathrm{mg} / \mathrm{l}$ & $90.00 \pm 5.00^{\text {ef }}$ & Creamish green callus \\
& $2.0 \mathrm{mg} / \mathrm{l}$ & $96.67 \pm 2.89^{\mathrm{f}}$ & Creamish yellow callus \\
& $3.0 \mathrm{mg} / \mathrm{l}$ & $85.00 \pm 5.00^{\mathrm{de}}$ & Creamish yellow callus \\
BAP+NAA & $4.0 \mathrm{mg} / \mathrm{l}$ & $55.00 \pm 5.00^{\mathrm{a}}$ & Creamish yellow callus \\
& $0.5 \mathrm{mg} / \mathrm{l}+0.5 \mathrm{mg} / \mathrm{l}$ & $90.00 \pm 5.00^{\mathrm{ef}}$ & Friable green callus \\
& $1.0 \mathrm{mg} / \mathrm{l}+0.5 \mathrm{mg} / \mathrm{l}$ & $96.67 \pm 2.89^{\mathrm{f}}$ & Greenish callus \\
& $2.0 \mathrm{mg} / \mathrm{l}+0.5 \mathrm{mg} / \mathrm{l}$ & $95.00 \pm 5.00^{\mathrm{f}}$ & Friable green callus \\
& $3.0 \mathrm{mg} / \mathrm{l}+0.5 \mathrm{mg} / \mathrm{l}$ & $75.00 \pm 5.00^{\mathrm{bc}}$ & Creamish green callus \\
& $4.0 \mathrm{mg} / \mathrm{l}+0.5 \mathrm{mg} / \mathrm{l}$ & $70.00 \pm 5.00^{\mathrm{b}}$ & Creamish green callus \\
\hline
\end{tabular}

Values represent the mean \pm SD. Means with the different letters in columns indicate significant differences at $5 \%$ level.
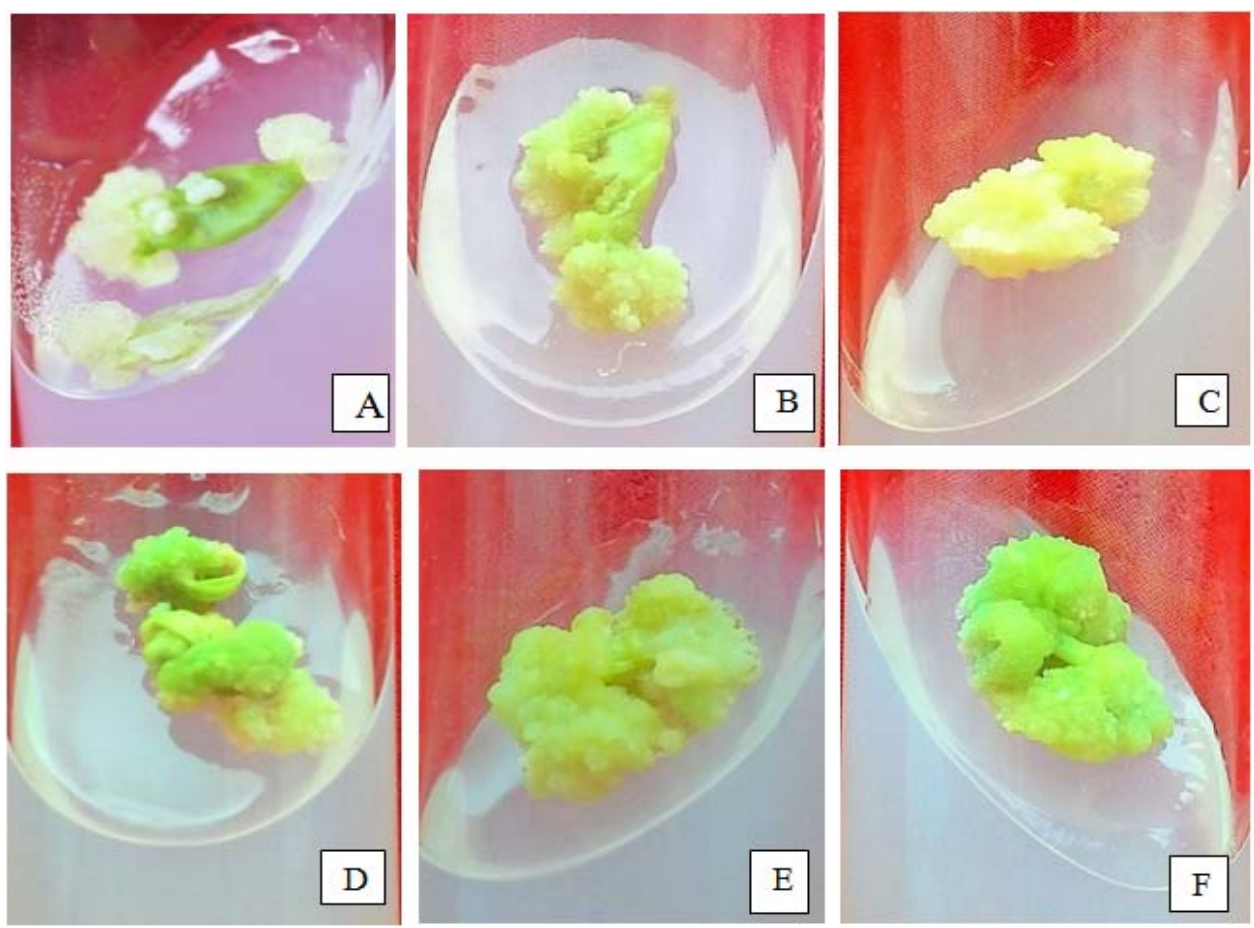

Fig. 1: A-F. In vitro callusing from leaf explants of D. arayalpathra. A-C: MS+2, 4-D (0.5 mg/l), (1 mg/l), (2 mg/l) respectively. D: MS+BAP $(0.5 \mathrm{mg} / \mathrm{l})+\mathrm{NAA}(0.5 \mathrm{mg} / \mathrm{l}), \mathrm{E}: \mathrm{MS}+\mathrm{BAP}(1 \mathrm{mg} / \mathrm{l})+\mathrm{NAA}(0.5 \mathrm{mg} / \mathrm{l}), \mathrm{F}: \mathrm{MS}+\mathrm{BAP}(2 \mathrm{mg} / \mathrm{l})+\mathrm{NAA}(0.5 \mathrm{mg} / \mathrm{l})$ 


\section{Phytochemical analysis}

The secondary metabolites produced by the plants play an important role in plant defence against prey, microorganisms, stress as well as interspecies protections. These secondary metabolites have been used as a drug from the time immemorial, hence screening of phytochemicals serve as the initial steps in predicting the potential active compounds in the plant extracts [18]. Phytochemical studies revealed the presence of alkaloids, flavonoids, proteins, phenols, tannins, steroids and terpenoids, phytosterols, glycosides, coumarins, carbohydrates, betacyanin, resins, phlobatannins, volatile oils. Ethanol, methanol and acetone were proven to be better solvents for the extraction of major phytochemicals compare to other solvents (table 2).

Table 2: Preliminary phytochemical analysis on fresh leaf and callus of D. arayalpathra

\begin{tabular}{|c|c|c|c|c|c|c|c|c|c|c|c|c|c|c|c|c|}
\hline \multirow[t]{2}{*}{ Tests } & \multicolumn{8}{|c|}{ Fresh leaf } & \multicolumn{8}{|c|}{ Fresh callus } \\
\hline & I & II & III & IV & V & VI & VII & VIII & I & II & III & IV & V & VI & VII & VIII \\
\hline Alkaloids & + & + & + & + & - & + & - & - & - & + & - & - & - & + & - & + \\
\hline Flavonoids & + & + & - & - & - & + & + & + & + & + & - & - & - & + & - & + \\
\hline Proteins & + & + & + & + & + & + & + & + & + & + & - & - & + & + & + & + \\
\hline Phenols & + & + & - & - & - & + & + & + & + & + & - & - & - & - & - & + \\
\hline Tannins & + & + & + & + & - & + & + & + & - & + & - & - & - & - & - & + \\
\hline Steroids andTerpenoids & + & + & + & + & - & - & + & - & - & - & - & - & - & - & - & + \\
\hline Phytosterols & + & + & + & + & - & - & + & - & - & - & - & - & - & - & - & + \\
\hline Glycosides & + & + & - & - & - & + & + & + & + & - & - & - & - & - & - & - \\
\hline Coumarins & + & + & + & + & - & + & - & + & - & + & + & + & - & + & - & - \\
\hline Carbohydrates & + & + & - & + & - & - & + & + & + & + & - & + & + & - & - & + \\
\hline Betacyanin & + & + & + & + & + & + & - & + & + & + & - & - & - & + & - & + \\
\hline Resins & + & + & - & - & - & - & - & - & + & + & + & - & + & - & - & + \\
\hline Phlobatannins & + & + & - & - & - & - & - & + & - & - & - & - & - & + & - & - \\
\hline Starch & - & - & - & - & - & - & - & - & - & - & - & - & - & - & - & - \\
\hline Volatile oils & + & + & - & - & - & + & - & + & - & - & - & - & - & - & - & + \\
\hline Emodols & - & - & - & - & - & - & - & - & - & - & - & - & - & - & - & - \\
\hline
\end{tabular}

I-Ethanol, II-Methanol, III-Petroleum ether, IV-Chloroform, V-Hexane, VI-Acetone, VII-Butanol, VIII-Aqueous

\section{Antibacterial activity}

The present study revealed the antibacterial activities of the leaf and callus extracts $(150 \mu \mathrm{g} / \mathrm{ml})$ against bacterial strains (Bacillus subtilis, Staphylococcus aureus, Escherichia coli, Klebsiella pneumoniae and
Pseudomonas fluorescence) by agar well diffusion method. Aqueous and methanol leaf extracts showed maximum inhibition against Klebsiella pneumoniae compared to other extracts (fig. 2). Whereas in callus, ethanol and petroleum ether extracts showed higher inhibitory activity against Escherichia coli and Bacillus subtilis (fig. 3).

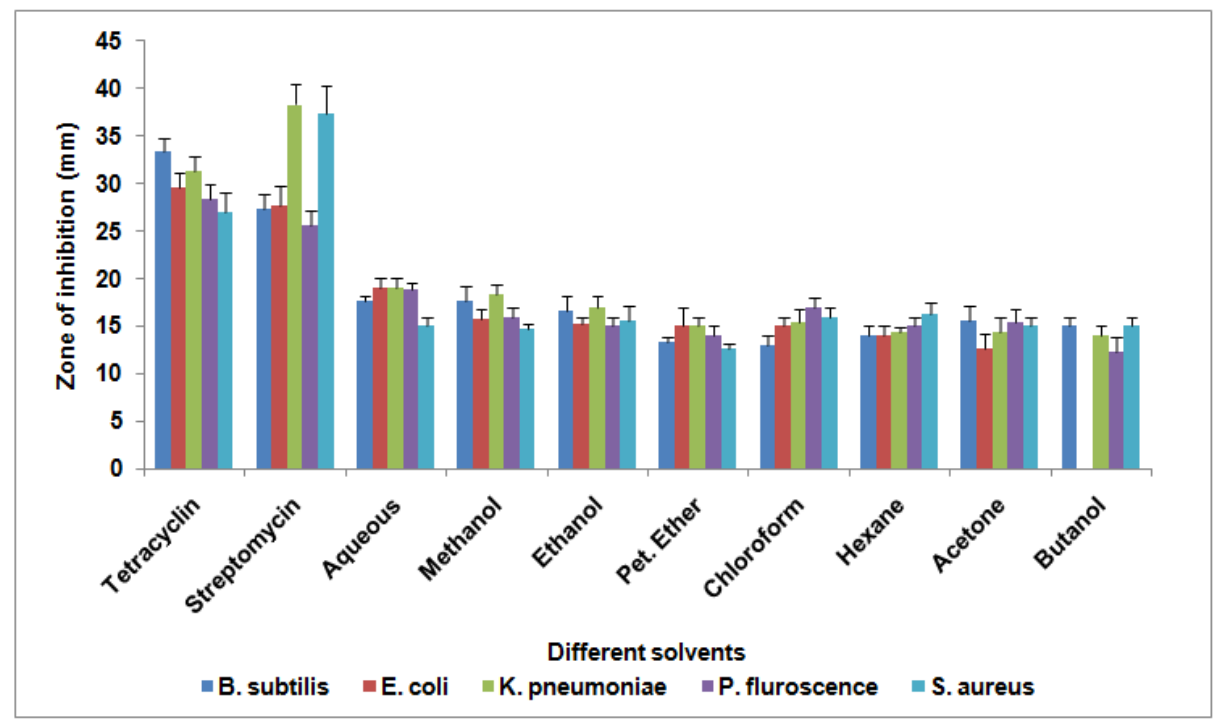

Fig. 2: Zone of inhibition on different solvents of $D$. arayalpathra fresh leaf, data are presented as the mean \pm SE of the mean of triplicates

\section{DISCUSSION}

Plants are important sources of potentially useful substances for the development of new therapeutic agents [19]. The aromatic roots of D. arayalpathra have been overexploited for therapeutic use leading to drastic reduction in the population of these species in the wild habitat. The plant biotechnology provides new tools for collection, multiplication and conservation of plant biodiversity by using in vitro culture techniques [20]. There are limited reports on micropropagation of D. arayalpathra [10, 21]. Therefore, the present study was investigated to find out the effective protocol for the micropropagation of $D$. arayalpathra using leaf explants.

The efficiency of callus induction depends on the type of growth regulators, explants source and culture medium. In our study, the green friable callus induction was observed on MS media supplemented with a lower concentration of BAP and NAA. Formation of green friable callus may be due to their role in DNA 
synthesis and mitosis [22]. Our results are in agreement with the studies of Umesh [23] and Sudha et al. [21] in Decalepis hamiltonii using nodal explants. Similar results were reported in other plant species (Amaranthus spp., and Ruta graveolens) wherein, callus induction was observed from leaf explants inoculated on MS medium supplemented with BA and NAA [24-25].

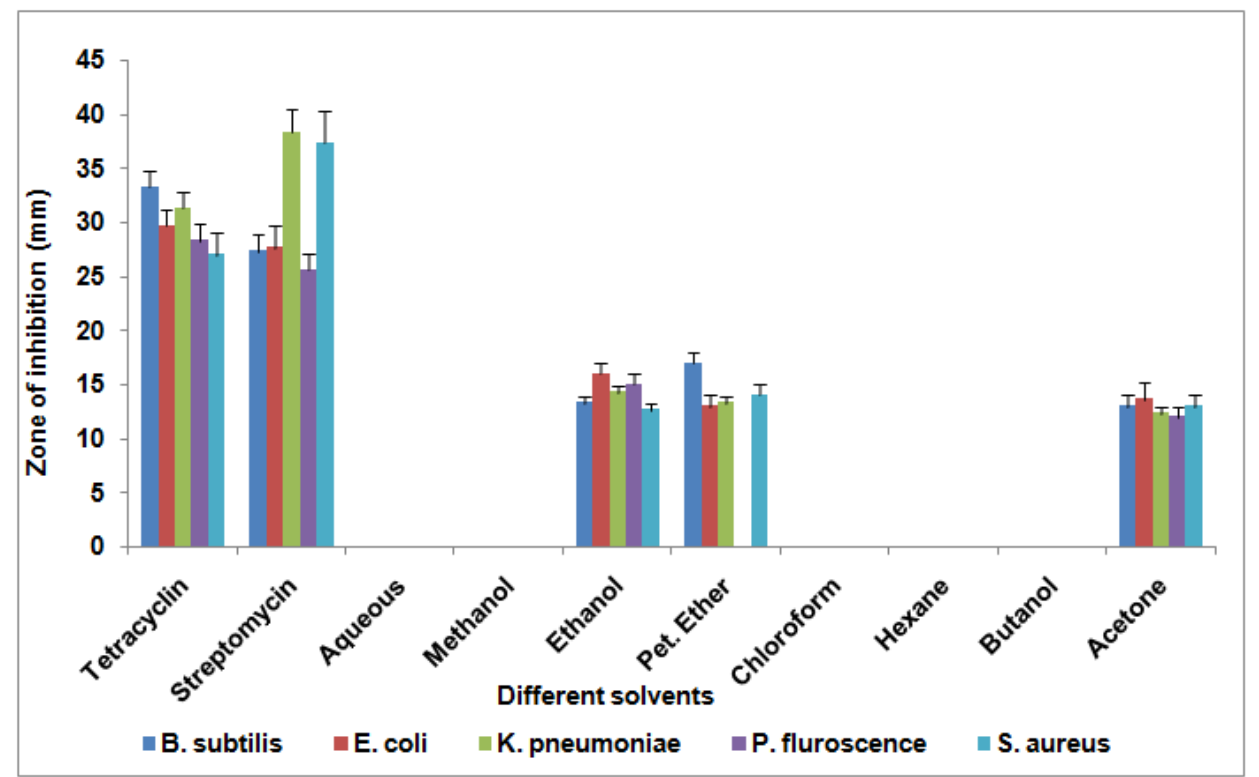

Fig. 3: Zone of inhibition on different solvents of $D$. arayalpathra leaf callus, data are presented as the mean \pm SE of the mean of triplicates

Phytochemical constituents present in plants such as alkaloids, flavonoids, and tannins etc., serves as a defense mechanism against predation by many microorganisms. Chandra and Kaneria [26] have reported that the accumulation of secondary metabolites may vary in different plant parts and leaf is one such plant parts which have highest accumulation of metabolites [27]. Our qualitative analysis revealed the presence of major phytochemicals in the leaf compared to callus. Previous studies reported lesser accumulation of phytochemicals in the callus compared to other plant parts [28, 29]. Aqueous, methanol and acetone extracts are the best solvents to isolate major phytochemicals compared to other solvents. Johnson et $a l$. [17] reported that major phytochemicals were extracted in ethanol and methanol leaf and callus extracts of Baliospermum montanum.

Plant extracts can be a good source of antibiotics against various bacterial pathogens. In the present study, antibacterial activities of leaf and callus extracts of $D$. arayalpathra were calculated by measuring the diameter of the zone around the well. The maximum inhibition was observed in leaf extracts against major pathogens compared to callus due to their lesser accumulation of secondary metabolites. Various workers have reported that root, leaf and callus extracts can inhibit both gram positive and gram negative bacteria [30-32]. The mode of action of antimicrobial agents may be due to interference with cell wall synthesis, inhibition of protein synthesis, interference with nucleic acid synthesis, and inhibition of a metabolic pathway [33].

\section{CONCLUSION}

In the present study, an efficient protocol was developed for callus induction from leaf explants of D. arayalpathra. The phytochemical analysis of the leaf and callus revealed the presence of bioactive compounds with antibacterial activity against many pathogens. Further studies have to be carried to characterize these antimicrobial compounds and large-scale production through in vitro propagation.

\section{CONFLICT OF INTERESTS}

No conflict of interest

\section{REFERENCES}

1. Sharma S, Shahzad A. An overview on decalepis; a genus of woody medicinal climbers. Open Sci Publications 2014;1:1-13.
2. Vedavathy S. Decalepis hamiltonii Wight and Arn-an endangered source of indigenous health drink. Nat Prod Radiance 2004;3:22-3.

3. Vijayakumar V, Pullaiah T. An ethno-medico-botanical study of Prakasam district, Andra Pradesh, India. Fitoterpia 1998; 69:483-9.

4. Harish R, Srivastava A, Divakar S, Shivanandappa T. Isolation of antioxidant compounds from the methanolic extract of the roots of Decalepis hamiltonii (Wight and Arn.). J Agric Food Chem 2005;53:7709-14.

5. Pushpangadan P, Rajasekharan A, Ratheeshkumar PK, Jawahar CR, Radhakrishnan K. Amrithapala Uanakia arayalpathra Joseph and Chandrasekharan), a new drug from the Kani tribe of Kerala. Anc Sci Life 1990;9:212-4.

6. Subramaniam A, Rajasekharan S, Latha PG, Evans DA, Pushpangadan P. Immuno-modulatory and antitumor activities of Janakia arayalpathra. Fitoterpia 1996;57:140-4.

7. Chopra RN, Nayar SI, Chopra LC, Asolkar LV, Kakkar KK. Glossary of Indian Medicinal Plants; Council of Scientific and Industrial Research, New Delhi; 1956.

8. Jacob KC. An unrecorded economic product Decalepis hamiltonii W. and Arn, family asclepidaceae. Madras Agric J 1937;25:176.

9. Sudha CG, Seeni S. Establishment and analysis of fast-growing normal root culture of Decalepis arayalpathra, a rare endemic medicinal plant. Curr Sci 2001;81:371-4.

10. Gangaprasad A, Decruse SW, Seeni S, Nair GM. Micropropagation and ecorestoration of Decalepis arayalpathra (Joseph and Chandra.) venter-an endemic and endangered ethnomedicinal plant of Western Ghats. Indian J Biotechnol 2005;4:265-70

11. Lee Y, Lee DE, Lee HS, Kim SK, Lee WS, Kim SH, et al. Influence of auxins, cytokinins and nitrogen on the production of rutin from callus and adventitious roots of the white mulberry tree (Morus alba L.). Plant Cell Tiss Org Cult 2011;105:9-19.

12. Dhanapal ACTN, Ming TW, Aung HP, Hao SJ. Preliminary screening of Artemisia argyi for antioxidant potentials. Int J Pharmacogn Phytochem Res 2016;8:347-55.

13. Harbone JB. Phytochemical Methods. Chapman and Hall Ltd, London; 1973. p. 33-80. 
14. Borah U, Dash B, Dash S, Deka J, Kalita J. Preliminary phytochemical screening and in vitro antimicrobial activity of ethanolic extract of whole aerial part of the herb Leucas plukenetii spreng (Family-Laminaceae). Int J Curr Pharm Res 2017;9:87-90.

15. Mohan B, Nayak JB, Sunil Kumar R, Shiva Kumari LP, Mohan CH, Rajani B. Phytochemical screening, GC-MS analysis of Decalepis hamiltonii Wight and Arn. An endangered medicinal plant. J Pharmacogn Phytochem 2016;5:10-6.

16. Tiwari P, Kumar B, Kaur M, Kaur G, Kaur H. Phytochemical screening and extraction; a review. Int Pharm Sci 2011;1:98-106.

17. Johnson M, Wesely EG, Zahir Hussain MI, Selvan N. In vivo and in vitro phytochemical and antibacterial efficacy of Baliospermum montanum (Willd.) Muell. Arg Asian Pacific J Trop Med 2010;3:894-7.

18. Chew YL, Chan EWL, Tan PL, Lim YY, Stanslas J, Goh JK. Assessment of phytochemical content, polyphenolic composition, antioxidant and antibacterial activities of Leguminosae medicinal plants in Peninsular Malaysia. BMC Complem Altern Med 2011;11:12.

19. Rajeswari A. Evaluation of phytochemical constituents, quantitative analysis and antimicrobial efficacy of potential herbs against selected microbes. Asian J Pharm Clin Res 2015;8:232-7.

20. Samydurai P, Saradha M, Ramakrishnan R, Santhosh Kumar S, Thangapandian V. Micropropagation prospective of cotyledonary explants of Decalepis hamiltonii Wight and Arn.an endangered edible species. Indian J Biotechnol 2016; 15: 256-60.

21. Sudha CG, Krishnan PN, Pushpangadan P, Seeni S. In vitro propagation of Decalepis arayalpathra, a critically endangered ethnomedicinal plant in vitro cell. Dev Biol-Plant 2005;41:648-54

22. Skoog F, Miller CO. Chemical regulation of growth and organ formation in plant tissue cultures in vitro. Symp Soc Exp Biol 1957;11:118-31.

23. Umesh TG. In vitro callus induction and antioxidant potential of Decalepis hamiltonii (Wight and Arn). Int J Pharm Pharm Sci 2014;6:452-6.
24. Pannu J, Thalwal S, Gupta A. Comparison of antimicrobial activity and phytochemical constituents of in vivo and in vitro grown Amaranthus spinosus plants. Int J Pharm Pharm Sci 2013;5:703-7.

25. Ahmad N, Faisal M, Anis M, Aref LM. In vitro callus induction and plant regeneration from leaf explants of Ruta graveolens $\mathrm{L}$. South Afr J Bot 2010;76:597-600.

26. Chandra S, Kaneria M. Indian nutraceutical plant leaves as a potential source of natural antimicrobial agents. In: A Mendez Vilas. Ed. Science against microbial Pathogens: Communicating Current Research and Technological Advances, Fomatex Research Center Publication, Spain; 2011. p. 1251-9.

27. Pires De Abreu LR, Ortiz RM, Castro de SC. HPLC determination of amoxicillin comparative bioavailability in healthy volunteers after a single dose administration. J Pharm Pharm Sci 2003;6:223-30.

28. Arumugam T, Ayyanar M, Koli Pillai YJ, Sekar T. Phytochemical screening and antibacterial activity of leaf and callus extracts of Centella asiatica. Bangladesh J Pharmacol 2011;6:55-60.

29. Thenmozhi M, Sivaraj R. In vitro evaluation of the antibacterial activity of Petunia leaf and callus extracts. J Agric Tech 2011;7:321-30.

30. Murugan VK, Arumugam T, Tamilvannan V, Umarani $\mathrm{K}$, Dhmoharan R, Ravikumar S. Phytochemical analysis and in vitro antibacterial properties of selected medicinal plants. Eur J Pharm Med Res 2015;2:189-94.

31. Prakash P, Thiyagarajan G, Manivasagaperumal R. Phytochemical screening and antibacterial activity of root extracts of Decalepis hamiltonii Wight and Arn. Int J Pharm Res Rev 2014;3:33-8.

32. Rajani B, Mohan B, Uma Devi M, Shiva Kumarich LP. Phytochemical studies and antibacterial activity of Decalepis hamiltonii wight and arn, an endangered medicinal plant. J Med Plant Studies 2016;4:88-91.

33. Laxmi A, Siddhartha S, Archana M. Antimicrobial screening of methanol and aqueous extracts of Swertia chirata. Int J Pharm Pharm Sci 2011;3:142-6. 